\title{
ASSESSMENT OF FOUR DIFFERENT DETERGENTS USED TO EXTRACT MEMBRANE PROTEINS FROM XYLELLA FASTIDIOSA BY TWO-DIMENSIONAL ELECTROPHORESIS
}

\author{
Luciana Di Ciero $^{1 *}$; Cláudia de M. Bellato ${ }^{2}$; Lyndel W. Meinhardt ${ }^{3}$; Fernanda Ferrari ${ }^{1}$; Rafael R. Castellari ${ }^{1}$; \\ Sérgio Marangoni ${ }^{1}$; José C. Novello ${ }^{1}$ \\ ${ }^{1}$ Departamento de Bioquímica, Universidade Estadual de Campinas, Campinas, SP, Brasil; ${ }^{2}$ Centro de Energia Nuclear na \\ Agricultura, Universidade de São Paulo, Piracicaba, SP, Brasil; ${ }^{3}$ Laboratório de Genômica e Expressão, Universidade Estadual \\ de Campinas, Campinas, SP, Brasil.
}

Submitted: October 05, 2003; Returned to authors for corrections: April 08, 2004; Approved: September 27, 2004

\begin{abstract}
Four different detergents, ASB 14, SB 3-10, CHAPS and Triton X100, were utilized to determine the optimal detergent for the solubilization of membrane proteins from the phytopathogenic bacterium Xylella fastidiosa. These proteins were differentially solubilized in distinct buffers containing the detergent and subjected to bidimensional electrophoresis within the non-linear $\mathrm{pH}$ range of 3-10. The detergents ASB 14 and SB 3-10 were the most effective revealing 221 and 157 spots, respectively. CHAPS and Triton X100 were less effective and revealed only 72 and 43 spots, respectively. MALDI-TOF tryptic peptide mass fingerprinting of 18 excised proteins from the ASB 14 treatment revealed that $83 \%$ were membrane proteins and that the theoretical efficiency of solubilization for ASB 14 was estimated to be $87 \%$. This study demonstrates the effectiveness of the detergent ASB 14 for the solubilization of membrane proteins from the bacterium $X$. fastidiosa.
\end{abstract}

Key words: $X$. fastidiosa, 2-DE, extraction, proteome, solubilization

\section{INTRODUCTION}

High-resolution two-dimensional electrophoresis (2-DE) allows for the quantitative and qualitative separation of complex proteins mixtures typically found in cellular extracts from organisms. IEF and SDS-PAGE are coupled in a method that separates proteins by isoelectric point and then by mass. Both of these steps are critically affected by the solubility of proteins prior to electrophoresis. Proteins can only be analyzed by 2-DE if they are kept in solution or solubilized during the entire process. Lack of optimal solubility results in poor visualization of the proteins, underrepresentation of some proteins such as membrane proteins, and a reduction in the abundance (25). Therefore, increased protein solubility is one of the major problems facing 2-DE and proteomics.

Membrane-bound and membrane-associated proteins are difficult to solubilize due to their hydrophobic nature (25). The solubility problems have been addressed, with varying success, by combining chaotropic agents, such as thiourea, urea, and guanidine hydrochloride, with detergents (sodium dodecyl sulfate, lithium dodecyl sulfate, Triton X-100, Nonidet P-40 and CHAPS) (4).

Traditionally, detergents such as Triton X-100 and Nonidet $\mathrm{P}-40$ have been used to solubilize membrane proteins in aqueous solution. The sulfobetaine CHAPS has become the detergent most commonly used in recent years $(19,20)$. Chevallet et al. (3) synthesized a range of novel more polar sulfobetaines with uncharged (zwitterions) head groups and long alkyl tails of more than 12 carbon atoms. The new detergents were tested on bovine neutrophile membrane proteins, Arabidopsis plasma membrane, E. coli outer membrane proteins and showed that the amidosulfobetaine type ASB-14 (4) and SB 3-10 $(15,19)$ were more efficient in urea-thiourea mixtures than the others tested. Since these detergents are commercially available, several

*Corresponding author. Mailing address: ESALQ - USP, Departamento de Ciências Florestais. Av. Pádua Dias, 11 - Caixa Postal 09. 13400-970, Piracicaba, SP, Brasil. E-mail: 1diciero@esalq.usp.br 
studies have been reported using them for proteomic analysis of membrane proteins $(14-19,23,24)$.

To analyze the solubilization of membrane protein from the gram-negative bacterium Xylella fastidiosa (X. fastidiosa), we tested four different detergents. $X$. fastidiosa is a xylem-limited slow growing bacterium that causes economically important plant diseases of sweet orange (citrus variegated chlorosis) $(3,22)$, and grapes (Pierce's disease) (7). This pathogen also causes leaf scorch of almond, coffee, plum, oleander, and mulberry (16). CVC is responsible for major losses in orange production and is a major threat to the citrus industry, since it is present in all of the main Brazilian citrus growing areas (8). The complete genome of a CVC strain, 31b9a5c, was sequenced and 2,904 genes were annotated on the chromosome and two plasmids (27). The annotation data are being verified by various Brazilian proteomic studies. As a part of these studies membrane protein analyses are being conducted due to their important roles in transport, metabolism, and in cellular and environmental adaptation.

The objective of this study was to compare the effectiveness of four commercially available detergents on the extraction of Xylella fastidiosa membrane proteins by 2-DE analysis.

\section{MATERIALS AND METHODS}

\section{Bacterial strain and culture condition}

This study analyzed the citrus-pathogenic $X$. fastidiosa strain 31b9a5c, which was isolated from Citrus sinensis (L.) Osbeck variety Valência cultivated in Macaubal, SP, Brazil. This isolate had its complete genome sequenced by Simpson et al. (27), which is available at the Xylella Genome Project Web site (http:/ /aeg.lbi.ic.unicamp.br/xf/). Bacterial cells were cultured on solid buffered-charcoal yeast extract (BCYE) medium (29) at $28^{\circ} \mathrm{C}$ for 21 days. Colonies were collected and immediately stored under liquid nitrogen for subsequent processing.

\section{Membrane protein extraction}

The $X$. fastidiosa membrane proteins were extracted by differential solubilization following the procedure described by Molloy et al. (15) with some modifications. Briefly, $40 \mathrm{mg}$ of $X$. fastidiosa cells were resuspended in $40 \mathrm{mM}$ Tris base and disrupted with the BioNeb ${ }^{\oplus}$ Cell Disruption System (Glas-Col, Terre Haute, IN) under pressure of $8 \mathrm{kgf} \mathrm{cm}^{-2}$ with nitrogen gas flow rate at 17.0 liter $\mathrm{min}^{-1}$. Before each sample was processed, the 5-10 mL BioNeb ${ }^{\circledast}$ acrylic cylinder was first washed with Milli-Q water and then rinsed with the buffer ( $40 \mathrm{mM}$ Tris-base). Samples were passed through $\mathrm{BioNeb}^{\circledR}$ system three times to obtain a complete cell disruption. Samples were kept on ice during all stages. Afterwards, samples were centrifuged at 12000 $\mathrm{x} g$ for $10 \mathrm{~min}$ at $4^{\circ} \mathrm{C}$. The pellet was washed twice with $40 \mathrm{mM}$ Tris base and the membrane proteins were extracted in a twostep protocol, as follows.
Step 1. The residual pellet was reconstituted in $5 \mathrm{~mL}$ of conventional solubilization solution [8 M urea, 4\% CHAPS, 100 $\mathrm{mM}$ DTT, $40 \mathrm{mM}$ Tris base and $0.5 \% \mathrm{v} / \mathrm{v}$ carrier ampholytes (CA) 3-10, pH 9.5] and centrifuged as described. The supernatant rich in cytoplasmic proteins was discarded and the insoluble pellet was solubilized in $200 \mu \mathrm{L}$ of $40 \mathrm{mM}$ Tris base and partitioned in four samples of $50 \mu \mathrm{L}$ each. Although the first step contained a high concentration of CHAPS (4\%), which can solubilize membrane proteins, our objective was to analyze the effectiveness of the different detergents to recovery insoluble proteins in the second step.

Step 2. Each of the four samples were centrifuged again and each sample was solubilized in a solution containing $7 \mathrm{M}$ urea / $2 \mathrm{M}$ thiourea, $70 \mathrm{mM}$ DTT, $0.5 \% \mathrm{v} / \mathrm{v}$ of CA 3-10 and one of detergents described below. The concentration of the detergent used in each solution was 1\% (w/v) of ASB 14 (solution 1), $2 \%$ v/v of SB 3-10 (solution 2); 4\% v/v of CHAPS (solution 3), and $4 \% \mathrm{v} / \mathrm{v}$ Triton X100 (solution 4). All detergents were from Calbiochem. The samples were mixed vigorously, centrifuged at $6000 \mathrm{x} g$ at room temperature and submitted to 2-DE.

The reproducibility of the results was confirmed by three independent experiments, each with three repetitions.

\section{Electrophoresis}

IEF was conducted with IPG Immobiline DryStrip pH3-10 non-linear (NL) $18 \mathrm{~cm}$ (Amersham Biosciences). Strips were rehydrated for $16 \mathrm{~h}$ with $350 \mu \mathrm{L}$ of IEF solution containing the solubilized membrane proteins. IEF was conducted in the IPGphor system (Amersham Biosciences) using the followed steps: $\mathrm{S} 1$ at $500 \mathrm{~V}$ for $1 \mathrm{~h} ; \mathrm{S} 2$ at $3500 \mathrm{~V}$ for $1 \mathrm{~h}$ and $\mathrm{S} 3$ at $8000 \mathrm{~V}$ until the focusing reached $60 \mathrm{kVh}$. Afterward, the strips were equilibrated with $50 \mathrm{mM}$ Tris-HCl pH 6.8; 6M Urea, 30\% Glycerol $(\mathrm{v} / \mathrm{v}) ; 2 \% \mathrm{SDS}(\mathrm{w} / \mathrm{v})$, and $2 \%$ DTT $(\mathrm{w} / \mathrm{v})$ at room temperature (RT) for $10 \mathrm{~min}$. Subsequently, the strips were re-equilibrated with the same solution except that DTT was replaced by $2.5 \%$ iodoacetamide and $0.005 \%$ of bromophenol blue at RT for 10 $\min$. Strips were then sealed with $0.1 \%$ agarose in the top 1.5 $\mathrm{mm}$ of a $14 \mathrm{x} 15 \mathrm{~cm}$ vertical $12.5 \%$ PAGE in a SE-600 system (Hoefer SE600). Electrophoresis was performed in the presence of $25 \mathrm{mM}$ Tris-HCl, $192 \mathrm{mM}$ Glycine and $0.1 \%$ SDS with constant voltage (90 V) for $30 \mathrm{~min}$ followed by constant amperage (30 $\mathrm{mA} / \mathrm{gel}$ ) at $10^{\circ} \mathrm{C}$ for 3 to $4 \mathrm{~h}$ or until the bromophenol blue reached the bottom of the gel. Afterwards, gels were rinsed with distilled water for $5 \mathrm{~min}$ and fixed overnight in $40 \%$ methanol and $10 \%$ acetic acid. The gels were silver-stained according to Blum et al. (1) without formaldehyde.

\section{Imaging Analysis}

After staining, 2-DE gels were digitally documented with a Personal densitometer SI (Molecular Dynamics) and analyzed with the Melanie program version 3 (Genebio, Geneva, SW). The calibration of $\mathrm{p} I / \mathrm{M} r$ was based upon standard protein 
spots with known $\mathrm{p} I$ and molecular masses. Parameters such as volume and area were used to compare the quantity of the protein spots from the gels and evaluate the proteins from the second extraction step.

\section{Peptide Mass Fingerprinting}

Eighteen differentially expressed protein spots from 2-DE gels were randomly chosen, excised and subjected to MALDITOF tryptic peptide mass fingerprinting to identify the peptides. Peptides were generated and extracted from the gel-separated proteins following established in gel trypsin digestion protocols (26). The peptides were analyzed on a Voyager DE-PRO MALDITOF mass spectrometer (Applied Biosystems). Prior to their application to the sample plate, the samples were purified using C18 ZipTip (Millipore), and eluted directly with a matrix solution of $2 \%(\mathrm{w} / \mathrm{v})$ alpha-cyano-hydroxycinnamic acid, $60 \%$ acetonitrile and $0.1 \%(\mathrm{v} / \mathrm{v})$ trifluoroacetic acid.

Bacterial proteins were identified by measuring tryptic peptide masses and using these data to search the $X$. fastidiosa genome database with the MS-Fit program (UCSF; http:// prospector.ucsf.edu/) (5).

\section{RESULTS AND DISCUSSION}

The purpose of our study was to assess, through 2-DE, the efficiency of four different commercially available detergents, ASB 14, SB3-10, CHAPS and Triton X-100 (Calbiochem) to solubilize membrane-bound or membrane-associated proteins from the plant-pathogenic bacterium, X. fastidiosa. To further optimize the procedure, differential protein solubility (15) was used together with the different detergents to sequentially separate proteins by their solubility, thus enriching the samples for membrane proteins. The efficiency of each detergent solution was determined by the number and volume of the visible spots on the gels analyzed by Melanie 3 (Genebio). The analysis of the gels with the samples solubilized with solution 1 (ASB 14) (Fig. 1a), solution 2 (SB 3-10) (Fig. 1b), solution 3 (CHAPS) (Fig. 1c) and solution 4 (Triton X100) (Fig. 1d) revealed, within the pH range 3-10 NL, 221, 157, 72 and 43 spots, respectively. These protein profiles obtained by 2-DE showed that the detergents ASB 14 and SB 3-10 were more efficient in solubilizing membrane proteins from $X$. fastidios a followed by CHAPS and finally Triton $\mathrm{X}-100$. The molecular weights (estimated through Melanie program) of the protein spots obtained with the various detergent treatments ranged from 15 to $97.9 \mathrm{kDa}$ for ASB-14, 15 to $56 \mathrm{kDa}$ for SB3-10, 17.8 to $61 \mathrm{kDa}$ for CHAPS and 17.8 to 63 $\mathrm{kDa}$ for Triton-X. Overall, the effectiveness of each detergent can be easily observed by the number and abundance of spots revealed between the isoelectric points 4.5 to 9.5 , and the molecular weight values within 17.9 and $88.1 \mathrm{kDa}$. Other studies have also shown the effectiveness of these sulfobetaines detergents for 2-DE analysis $(4,6,12,15)$.

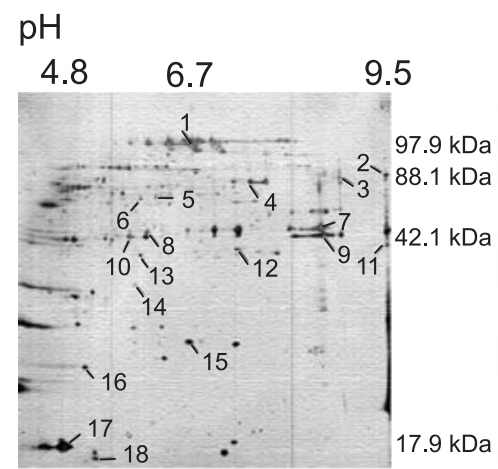

A. $10 \%$ ASB-14

(221 spots)

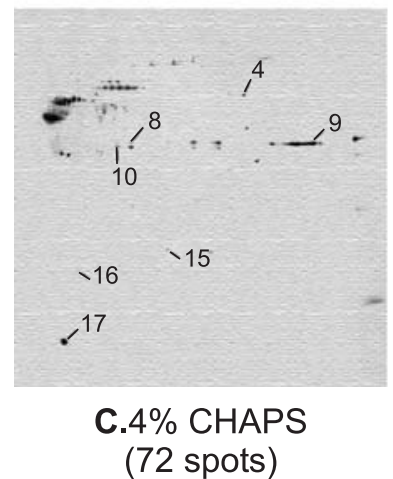

(72 spots)

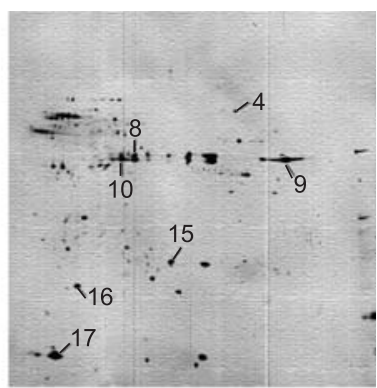

B. $1 \%$ SB3-10 (157 spots)

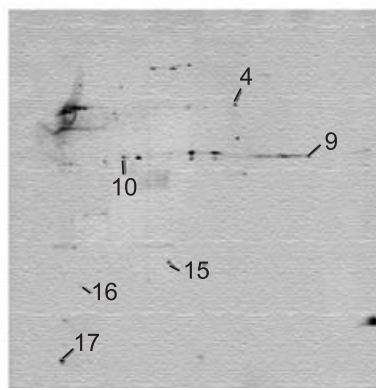

D.4\% Triton $\times 100$ (157 spots)

Figure 1. 2-DE analyses of four commercially available surfactants on membrane proteins from Xylella fastidiosa. Membrane proteins were differentially extracted according to Molloy et al. (15) and solubilized in a solution containing $7 \mathrm{M}$ urea / $2 \mathrm{M}$ thiourea, $70 \mathrm{mM}$ DTT, $0.5 \% \mathrm{v} / \mathrm{v}$ of CA 3-10 and one of the detergents as indicated. All gels are oriented with the acid $\mathrm{pH}$ at the left and the molecular markers at the right. Numbers indicate the protein spots chosen for MALDI-TOF mass fingerprint. Their presence or absence on the gel illustrates the efficiency of the detergent.

Eighteen protein spots (1 to 18 ) from the gel with samples treated with ASB 14 were randomly chosen for MALDI-TOF mass fingerprint analysis (Table 1). The ORFs that refer to the sequence of each spot are described in Table 1 . These results indicate that the procedure used (15) with ASB 14 enriched the samples for membrane proteins, with $15(83 \%)$ of the spots identified as "membrane proteins" (Table 1). Of these 15 membrane proteins, two were inner membrane proteins (IMPs), nine were outer membrane proteins (OMPs), and four were periplasmatic proteins (PMs). The cytoplasmic proteins identified in the sample were the bacterioferritin (spot number 17, ORF Xf0395), and a conserved hypothetical protein (spot number 18 , ORF Xf1808). Although an elongation factor Tu (EF-Tu) (spot number 10, ORF Xf2628/2640) was considered as a cytoplasmic 
Table 1. Proteins of Xylella fastidiosa obtained from samples treated with ASB 14, identified on 2-DE gels and sequenced through MALDI-TOF mass fingerprintXF0339.

\begin{tabular}{|c|c|c|c|c|c|}
\hline $\begin{array}{l}\text { Number on } \\
\text { the Gel }\end{array}$ & ORF & gene product & $\mathrm{p} i$ & $\begin{array}{l}\text { MW } \\
\text { (kDa) }\end{array}$ & $\begin{array}{l}\text { Sub-cellular } \\
\text { localization }\end{array}$ \\
\hline 1 & Xf0339 & Conserved hypothetical protein & 6.70 & 97.9 & Outer membrane \\
\hline 2 & Xf0521 & Conserved hypothetical protein & 9.49 & 88.1 & Inner membrane \\
\hline 3 & Xf1363 & Soluble Lytic Murein Transglycosylase Precursor & 8.96 & 80.0 & Outer Membrane \\
\hline 4 & Xf0781 & Lipase/Esterase & 6.23 & 64.3 & Outer Membrane \\
\hline 5 & Xf2544 & Pilus biogenesis protein & 5.76 & 63.0 & Periplasmic \\
\hline 6 & Xf1476 & ABC Transport membrane Protein & 5.78 & 54.1 & Outer Membrane \\
\hline 7 & Xf2586 & Outer Membrane Export Factor & 8.51 & 49.5 & Outer Membrane \\
\hline 8 & Xf0838 & Peptidyl-Prolyl Cis-Trans Isomerase & 5.94 & 50.8 & Periplasmic \\
\hline 9 & Xf0343 & Outer Membrane Protein & 8.45 & 42.2 & Outer Membrane \\
\hline 10 & Xf $2628 / 2640$ & Elongation Factor Tu & 5.48 & 42.9 & Cytoplasmic \\
\hline 11 & Xf0975 & Polyphosphate-Selective Porin O & 9.17 & 43.7 & Outer Membrane \\
\hline 12 & Xf1097 & Nicotinate Phosphoribosyl Transferase & 6.83 & 45.0 & Periplasmic \\
\hline 13 & Xf0369 & Fimbrial assembly membrane protein & 5.28 & 42.1 & Inner membrane \\
\hline 14 & $\mathrm{Xf} 2283$ & Hypothetical Protein & 5.91 & 34.3 & Outer Membrane \\
\hline 15 & Xf1840 & Conserved Hypothetical Protein & 6.37 & 25.1 & Periplasmic \\
\hline 16 & Xf2392 & Autolytic Lysozyme & 4.73 & 23.3 & Outer Membrane \\
\hline 17 & Xf0395 & Bacteriferritin & 4.78 & 17.9 & Cytoplasmic \\
\hline 18 & Xf1808 & Conserved Hypothetical Protein & 5.12 & 11.6 & Cytoplasmic \\
\hline
\end{tabular}

protein based on previous annotation, EF-Tu has been found to be associated with bacterial periplasm (2). If the mass fingerprint data can be used to extrapolate the total number of membrane proteins obtained from the ASB 14 treatment (at an 83\% recovery) then 183 of the 221 protein spots are membrane proteins. Analysis of the $X$. fastidiosa genomic database predicts 210 membrane proteins (approximately $7 \%$ of the total genome), thus giving a theoretical efficiency of solubilization for this treatment of $87 \%$ (number of membrane protein observed/predicted total number of membrane proteins in the genome $\mathrm{x} 100$ ). While this is a reasonable approach, caution should be taken with this calculation since some $40 \%$ of the ORF of the $X$. fastidiosa genome have no functional assignment and due to the possibility of differentially expressed membrane proteins. Furthermore, to explain the presence of the "hydrophilic proteins" in the membrane (hydrophobic) fraction, Herbert et al. (10) noted that not all proteins that are difficult to solubilized are "hydrophobic" based on the GRAVY scale (30). This insolubility of "hydrophilic" proteins could also be due to hydrophobic domains that are outweighed by a majority of hydrophilic residues (10).

Since there were protein spots that were detected in all gels, such as 4 (Xf0781), 9 (Xf0343), 10 (Xf2628/2640), 15 (Xf1840), 16 (Xf2392) and 17 (Xf0395), we used them as standards to evaluate the solubility efficiency of each detergent. Of these, spot 9 is known to be an abundant outer membrane protein (28), and the different detergents tested affected its solubility. Better protein solubilization was achieved with the ASB-14 detergent, however, other protein spots, such as spots 8 (Xf0838) and 10, showed slightly better solubility with the SB3-10 detergent. These results suggest that membrane protein solubility is highly dependent on the type of detergent utilized and protocols must be tailored according to the proteins of interest.

\section{CONCLUDING REMARKS}

Membrane-associated proteins of Gram-negative bacteria are key molecules that mediate important cellular functions. A number of them are involved in the flow of ions and nutrients in and out of the cells, transport of toxins and metabolites, and signal transduction across the bilayer (12). The expression of these proteins gives information regarding cellular function and they can be potential targets for control mechanism, especially in the case of pathogenic bacteria (10). While membraneassociated proteins are extremely important, 2-DE analysis of these proteins underrepresents this group.

The procedure used in this study was able to improve one of the major drawbacks of 2-DE, which is the detection of hydrophobic proteins (8). The choice of detergents utilized to solubilize the proteins for 2-DE can significantly alter the results, especially for hydrophobic proteins such as membrane and membrane-bound proteins, thereby making the detergent a key factor in the development of protocols for proteomic studies. 


\section{RESUMO}

\section{Avaliação de quatro detergentes utilizados para solubilização de proteínas de membrana de Xylela fastidiosa empregando eletroforese bidimensional}

O objetivo deste trabalho foi comparar a eficiência da solubilização de quatro detergentes comercialmente disponíveis, ASB 14, SB 3-10, CHAPS e Triton X100, na extração de proteínas de membrana da bactéria Xylella fastidiosa para estudos proteômicos. Estas proteínas foram solubilizadas em duas etapas em tampões diferenciados pelos detergentes e submetidas à eletroforese bidimensional (2-DE) em uma faixa de pH não linear de 3-10. Os detergentes ASB 14 e SB 3-10 foram os mais efecientes, revelando 221 e 157 proteínas, respectivamente, enquanto que o CHAPS e o Triton X100 resultaram somente 72 e 43 proteínas, respectivamente. A identificação das proteínas foi feita por 'peptide mass fingerprinting' em espectrometria de massa MALDI-TOF, através de peptídeos obtidos por digestão com tripsina in gel. Os 18 spots de proteínas do gel com tratamento com ASB 14 mostrou que $83 \%$ eram proteínas de membrana. Este estudo concluiu que o detergente ASB-14 foi o mais eficiente na solubilização de proteínas de membrana de Xylella fastidiosa.

Palavras-chave: bactéria, proteoma, solubilização, eletroforese bidimensional.

\section{REFERENCES}

1. Berrier, C.; Garrigues, A.; Richarme, G.; Ghazi, A. Elongation factor $\mathrm{Tu}$ and DnaK are transferred from the cytoplasm to the periplasm of Escherichia coli during osmotic downshock presumably via the mechanosensitive channel mscL. J. Bacteriol., 182:248-51, 2000.

2. Blum, H.; Beier, H.; Gross, H.J. Improved silver staining of plant proteins, RNA and DNA in polyacrylamide gels. Electrophoresis, 8:93-99, 1987.

3. Chang, C.J.; Garner, M.; Zreik, L.; Rosetti, V.; Bove, J. M. Culture and serological detection of xylem-limited bacterium causing citrus variegated chlorosis and its identification as a strain of Xylella fastidiosa. Curr. Microbiol., 27:137-142, 1993.

4. Chevallet, M.; Santoni,V.; Poinas, A.; Rouqié, D.; Fuchs, A.; Kieffer,S.; Rossignol, M.; Lunardi, J.; Garin, J.; Rabilloud, T. New zwitterionic detergents improve the analysis of membrane proteins by two-dimensional electrophoresis. Electrophoresis, 19:19011909, 1998

5. Clauser K.R.; Baker P.R.; Burlingame A.L. Role of accurate mass measurement $( \pm 10 \mathrm{ppm})$ in protein identification strategies employing MS or MS/MS and database searching. Anal. Chem. 71:2871-2882, 1999

6. Cordwell, S.J.; Nouwens, A.S.; Verrills, N.M.; Basseal, D.J.; Walsh, B.J. Subproteomics based upon protein cellular location and relative solubilities in conjunction with composite two-dimensional electrophoresis gels. Electrophoresis, 21:1094-103, 2000.

7. Davis, M.J.; Purcell, A.H.; Thomson, S.V. Pierce's disease of grapevines: isolation of the causal bacterium. Science, 199:75-77, 1978
8. Amaro, A.A.; Maia, M.L.; Gonzales, M.A. Economic effects originated from citrus variegated chlorosis. In: Donadio, L.C.; Moreira, C.S. (Eds.), Citrus Variegated Chlorosis, Est. Exp. Citricultura, Bebedouro, SP, Brazil, 1998, p.123-139.

9. Fountoulakis, M.; Takács, B. Effect of strong detergents and chaotropes on the detection of proteins in two-dimensional gels. Electrophoresis, 22:1593-602, 2001.

10. Herbert, B.R.; Molloy, M.P.; Gooley, B.A.A.; Walsh, J.; Bry- son, W.G.; Williams,K.L. Improved protein solubility in two-dimensional electrophoresis using tributyl phosphine as reducing agent. Electrophoresis, 19:845-851, 1998.

11. Heumann D.; Roger, T. Initial responses to endotoxins and Gramnegative bacteria. Clin. Chim. Acta, 323:59-72, 2002.

12. Leimgruber, R.M.; Malone, J.P.; Radabaugh, M.R.; LaPorte, M.L.; Violand B.N.; Monahan J.B. Development of improved cell lysis, solubilization and imaging approaches for proteomic analyses. Proteomics, 2:135-44, 2002.

13. Lengeler, J.W.; Drews, G.; Schlegel, H.G. Biology of the Prokaryotes, Blackwell Science, Inc. Malden, MA, USA, 1999.

14. Molloy, M.P.; Herbert, B.R.; Slade, M.B.; Rabilloud, T.; Nouwens, A.S.; Williams K.L.; Gooley A.A. Proteomic analysis of the Escherichia coli outer membrane J. Biochem., 267:1-12, 2000

15. Molloy, M.P.; Phadke, N.D.; Maddock, J.R.; Andrews, P.C. Twodimensional electrophoresis and peptide mass fingerprinting of bacterial outer membrane proteins. Electrophoresis, 22:1686-1696, 2001

16. Molloy, M.P.; Herbert, B.R.; Walsh, B.J.; Tyler, M.I.; Traini, M.; Sanchez, J.C.; Hochstrasser, D.F.; Williams K.L.; Gooley A.A Extraction of membrane proteins by differential solubilization for separation using two-dimensional gel electrophoresis Electrophoresis, 19:837-844, 1998

17. Nouwens, A.S.; Cordwell, S.J.; Larsen, M.R.; Molloy, M.P.; Gillings, M.; Willcox, M.D.; Walsh, B.J. Complementing genomics with proteomics: the membrane subproteome of Pseudomonas aeruginosa PAO1 Electrophoresis, 21:3797-3809, 2000.

18. Purcell, A.H.; Hopkins, D.L. Fastidious xylem-limited bacterial plant pathogens. Annu. Rev. Phytopathol., 34:131-151, 1996.

19. Rabilloud, T. Solubilization of proteins for electrophoretic analysis, Electrophoresis, 17:813-829, 1996

20. Rabilloud, T.; Adessi, C.; Giraudel, A.; Lunardi, J. Improvement of the solubilization of proteins in two-dimensional electrophoresis with immobilized pH gradients. Electrophoresis, 18:307-316, 1997.

21. Righetti, P.G. editors, Isoelectric Focusing: Theory, Methodology and Applications, Elsevier Biomedical Press, Amsterdam, 1983, pp.1-386.

22. Rossetti, V.M.; Garnier, J.M.; Bové, M.J.G.; Beretta, A.R.R.; Teixeira, J.A.; Quaggio, J.A.; De Negri, J.D. Presénce de bactéries dans le xyléme d'orangers atteints de chlorose variegée, une nouvelle maladie des agrumes au Brésil. C.R. Acad. Sci., 310:345-349, 1990

23. Santoni, V.; Doumas, P.; Rouquie, D.; Mansion, M.; Rabilloud, T.; Rossignol, M. Large scale characterization of plant plasma membrane proteins. Biochemie, 81:655-661, 1999.

24. Santoni, V.; Kieffer, S.; Desclaux, D.; Masson, F.; Rabilloud, T. Membrane proteomics: Use of additive main effects with multiplicative interaction model to classify plasma membrane proteins according to their solubility and electrophoretic properties. Electrophoresis, 21:3329-3344, 2000.

25. Santoni, V.; Molloy, M.P.; Rabilloud, T. Membrane proteins and proteomics: Un amour impossible? Electrophoresis, 21:1054-1070, 2000

26. Schevechenko, A.; Wilm, M.; Vorm, O.; Mann, M. Mass spectrometric sequencing of proteins from silver-stained polyacrylamide gels. Anal. Chem., 68:850-858, 1996.

27. Simpson, A.J.G.; Reinach, F.C.; Arruda, P.; Abreu, F.A.; et al. The genome sequence of the plant pathogen Xylella fastidiosa. Nature, 406:151-157, 2000. 
28. Smolka, M.B.; Martins, D.; Winck, F.V.; Santoro, C.E.; Castellari, R.R.; Ferrari, F.; Brum, I.J.; Galembeck, E.; Coletta-Filho, H.D.; Machado, M.A.; Marangoni, S.; Novello, J.C. Proteome analysis of the plant pathogen Xylella fastidiosa reveals major cellular and extracellular proteins and a peculiar codon bias distribution. Proteomics. Proteomics, 3:224-237, 2003.

29. Wells, J.M.; Raju, B.C.; Nyland, G.; Lowe S.K. Medium for Isolation and Growth of Bacteria Associated with Plum Leaf Scald and
Phony Peach Diseases. Appl. Environ. Microbiol., 42:357-363, 1981.

30. Wilkins, M.R.; Gasteiger, E.; Gooley, A.A.; Herbert, B.R.; Molloy, M.P.; Binz, P.A.; Ou, K.; Sanchez, J.C.; Bairoch, A.; Williams, K.L.; Hochstrasser, D.F. High-throughput mass spectrometric discovery of protein post-translational modifications. J. Mol. Biol., 289:64557, 1999. 